\title{
Serpiginous choroiditis
}

\author{
L. LAATIKAINEN AND H. ERKKILÄ \\ From the Helsinki University Eye Hospital, Helsinki, Finland
}

Serpiginous or geographic choroiditis is a descriptive name for insidious disseminated choroiditis characterized by multiple, confluent foci of exudate and scar formation, especially in the superficial portion of the choroid. Fluorescein angiographic and histological studies have revealed disappearance of the choriocapillaris and of the pigment epithelium (Hyvärinen, Maumenee, George, and Weinstein, I969). Schlaegel (1969) and Maumenee (1970) stated that some cases of serpiginous choroiditis are caused by choroidal inflammation, but some are the result of choroidal vascular abiotrophy and therefore degenerative in origin.

\section{Material}

This report deals with nine patients suffering from serpiginous choroiditis. Four had no signs of earlier choroidal inflammation, and in five old choroidal scars were present.

\section{Case reports}

(A) FOUR GASES Without EARLIER GHOROIDAL GHANGES (Table I)

Two female patients (Cases $I$ and 2) had uniocular serpiginous choroiditis, and two male patients (Cases 3 and 4) had both eyes simultaneously involved.

Table I Clinical findings in Group A. No earlier choroidal changes

\begin{tabular}{|c|c|c|c|c|c|c|c|c|}
\hline \multirow{2}{*}{$\begin{array}{l}\text { Case } \\
\text { no. }\end{array}$} & \multirow[t]{2}{*}{ Sex } & \multirow{2}{*}{$\begin{array}{l}\text { Age } \\
(y r s)\end{array}$} & \multirow[t]{2}{*}{ Eye } & \multicolumn{2}{|c|}{ Visual acuity } & \multirow{2}{*}{$\begin{array}{l}\text { Time cf recovery } \\
\text { (mths) }\end{array}$} & \multirow[t]{2}{*}{ Other findings } & \multirow[t]{2}{*}{ Therapy } \\
\hline & & & & Worst & Recovered & & & \\
\hline 1 & $\mathbf{F}$ & 20 & $\begin{array}{l}\mathrm{R} \\
\mathrm{L}\end{array}$ & $\begin{array}{l}0 \cdot 25 \\
1 \cdot 0\end{array}$ & 0.6 & 13 & AST 500 & $\begin{array}{l}\text { Penicillin, sulphatrimethoprim, } \\
\text { prednisone }\end{array}$ \\
\hline 2 & $\mathbf{F}$ & 21 & $\begin{array}{l}\mathbf{R} \\
\mathbf{L}\end{array}$ & $\begin{array}{l}0 \cdot 5 \\
1 \cdot 6\end{array}$ & $\overline{0.5}$ & $2 *$ & $\overline{-}$ & Streptomycin, INH, PAS \\
\hline 3 & M & 27 & $\begin{array}{l}\mathrm{R} \\
\mathrm{L}\end{array}$ & $\begin{array}{l}0.5 \\
1.6\end{array}$ & $1 \cdot 3$ & $2 *$ & $\begin{array}{l}\text { Acute respiratory infection } \\
1 \text { wk earlier }\end{array}$ & Streptomycin, INH, PAS \\
\hline 4 & $\bar{M}$ & 19 & $\begin{array}{l}\mathrm{R} \\
\mathrm{L}\end{array}$ & $\begin{array}{l}\overline{0 \cdot 5} \\
1 \cdot 0\end{array}$ & $\begin{array}{l}1 \cdot 0 \\
1 \cdot 0\end{array}$ & $\overline{2^{*}}$ & $\begin{array}{l}\text { Acute respiratory infection } \\
2 \text { wks earlier } \\
\text { AST } 400 \\
\text { Mother had pulmonary } \\
\text { tuberculosis } 10 \text { yrs earlier }\end{array}$ & INH, penicillin, prednisone \\
\hline
\end{tabular}

* Time of onset not known $\quad$ AST $=$ antistreptolysin titre $\quad$ INH = isoniazid $\quad$ PAS = para-amino salicylic acid

Blurring of vision was the only symptom. The worst visual acuity varied from 0.25 to $\mathrm{I} \cdot 6$ in the eyes affected, and small central and/or paracentral scotomas, both absolute and relative, were present. A few cells were seen in the vitreous. Ophthalmoscopy showed small greyish, disc-like or circular, confluent lesions and choroidal scars with slight pigment dispersion and depigmentation of the pigment epithelium in a serpiginous configuration (Fig. 1). In five out of the six diseased eyes, the macula was involved. The amount of exudation was more intense in the uniocular cases, and slight oedema of the optic disc and congestion of the retinal veins and capillaries could also be seen. 


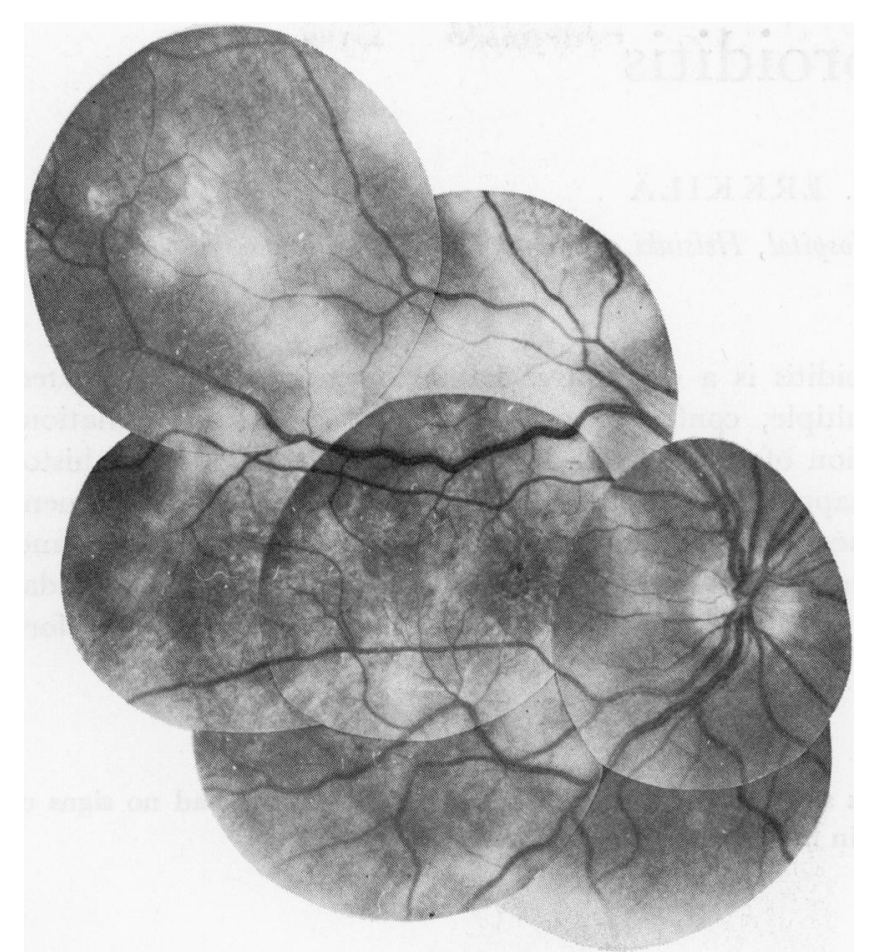

FIG. I Serpiginous configuration of acute lesions in right upper temporal region in Case I. In the macular area, resolution and scarring can already be seen

Fluorescein angiography of the active lesions showed delayed filling of the choriocapillaris, whereas areas of resolution showed rapid accumulation of fluorescein in the degenerating tissue (Fig. 2 A, B). In the late angiogram, hyperfluorescence could also be seen in the active areas (Fig. $2 \mathrm{C}$ ). In the uniocular cases, remarkable changes were also found in the retinal vessels (Figs 2 B and $3 \mathrm{~A}, \mathrm{~B}$ ). There was venous congestion with endothelial damage and thickening of the vessel walls as well as extravasation of fluorescein into the surrounding retina. Capillary congestion and leakage of the dye was also seen on the optic disc. In the binocular cases, no changes were seen in the retinal or papillary vessels.

After resolution of the process, large confluent scars became visible. The fluorescein angiogram showed disappearance of the choriocapillaris and the pigment epithelium, but the large choroidal vessels appeared normal (Fig. $3 \mathrm{~A}$ ). Hyperfluorescence at the edge of the scars indicates an intact choriocapillaris with diffusion of the dye into the scar tissue.

Healing of the individual lesions took place in 2 to 4 weeks, but new lesions appeared up to 12 months after the initial ones. After recovery, central visual acuity varied from 0.5 to 1.6 , small absolute and relative scotomas were present in the visual field, the EOG showed subnormal values, and the ERG was normal in the affected eyes.

(B) GASES WITH EARLIER GHOROIDAL SGARS (Table II, overleaf)

Five patients, one female and four males, had local or disseminated serpiginous choroidal scars in one eye and an active disease in the other.

In the initially affected eye, wide disseminated scars with macular involvement were present in three cases $(5,6$, and 9) (Fig. 4, overleaf), whereas the other two (Cases 7 and 8) showed a more localized scar without macular affection. 

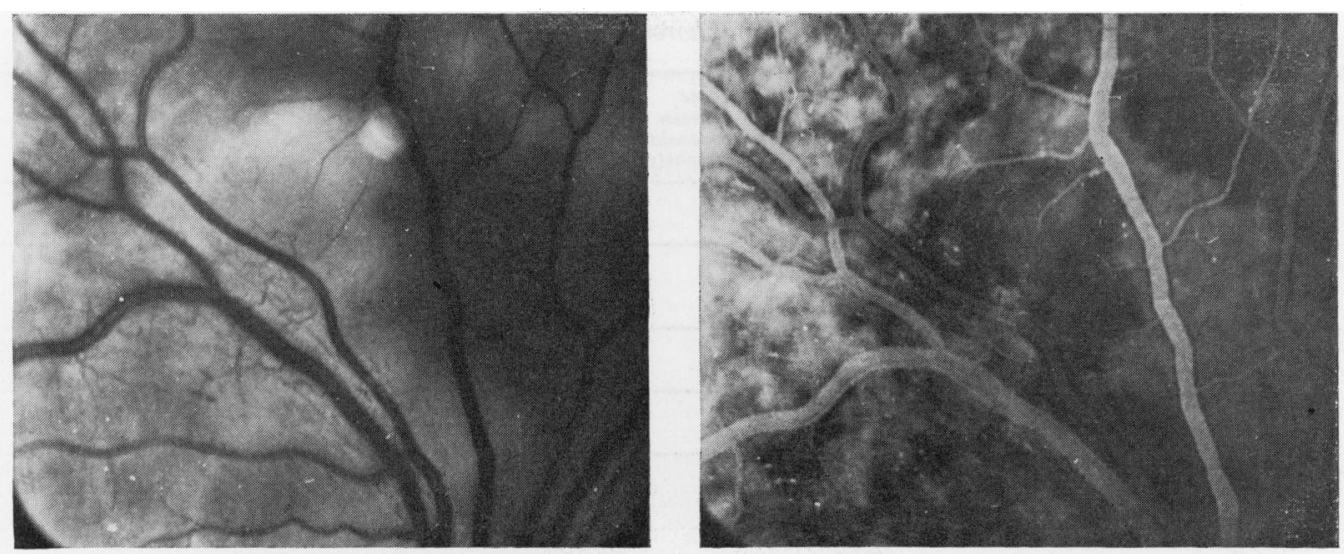

(B)

(C)

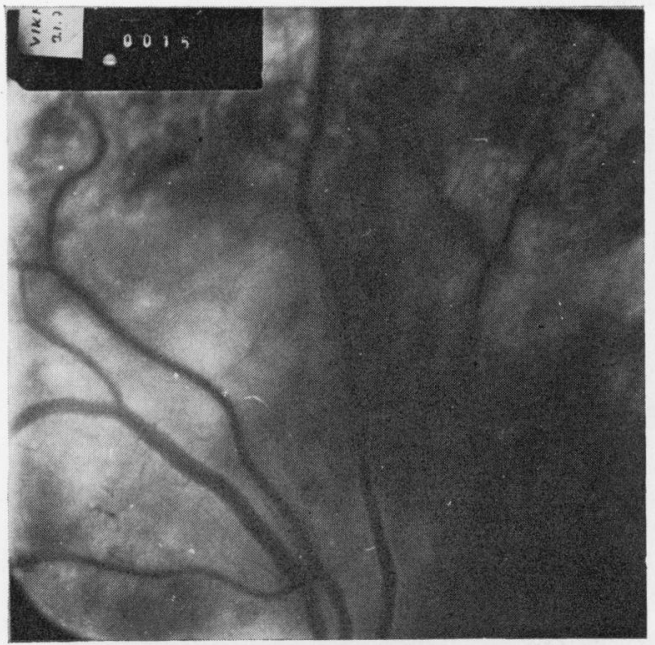

FI G. 2 Fluorescein angiogram of right eye of Case I 2 months later than in Fig. I, showing delayed filling $(B)$ but marked late staining $(C)$ of the fresh lesions. Damage of the vessel walls and congestion can also be seen in the retinal veins $(B)$
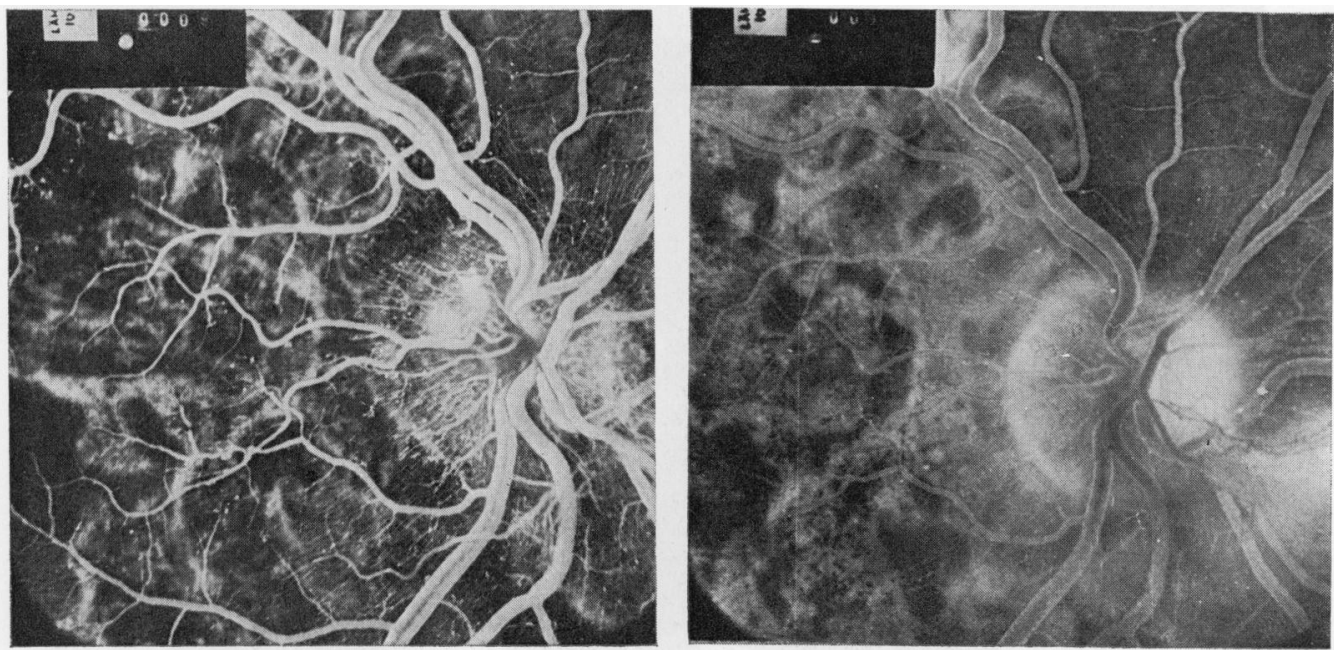

FIG. 3 Fluorescein angiogram of right eye of 'Case 2, showing resolution of choroidal lesions and retinal venou congestion as well as capillary congestion and leakage on the optic disc $(A, B)$ 
Table II Clinical findings in Group B. Old choroidal scars in the fellow eye

\begin{tabular}{|c|c|c|c|c|c|c|c|c|c|}
\hline \multirow{2}{*}{$\begin{array}{l}\text { Case } \\
\text { no. }\end{array}$} & \multirow[t]{2}{*}{ Sex } & \multirow{2}{*}{$\begin{array}{l}\text { Age } \\
\text { (yrs) }\end{array}$} & \multirow[t]{2}{*}{ Eye } & \multicolumn{2}{|c|}{ Visual acuity } & \multirow{2}{*}{$\begin{array}{l}\text { Time of } \\
\text { recovery } \\
(\text { mths })\end{array}$} & \multirow{2}{*}{$\begin{array}{l}\text { Time } \\
\text { between } \\
\text { binocular } \\
\text { attacks(yrs) }\end{array}$} & \multirow{2}{*}{$\begin{array}{l}\text { Other findings } \\
\text { ) }\end{array}$} & \multirow[t]{2}{*}{ Therapy } \\
\hline & & & & Worst & Recovered & & & & \\
\hline$\overline{5}$ & $\mathbf{M}$ & 35 & $\begin{array}{l}\mathrm{R} \\
\mathbf{L}\end{array}$ & $0 \cdot 1$ & $\begin{array}{l}1 \cdot 0 \\
0 \cdot 8\end{array}$ & * & $*$ & $\begin{array}{l}\text { Acute respiratory infection } \\
2 \mathrm{mths} \text { earlier }\end{array}$ & Streptomycin, INH, PAS \\
\hline 6 & $\mathbf{M}$ & 33 & $\mathbf{R}$ & $1 \cdot 0$ & $\begin{array}{l}\text { CF } 5 \mathrm{~m} \\
1.0\end{array}$ & 7 & 4 & $\begin{array}{l}\text { Virus meningitis } 7 \mathrm{mths} \\
\text { before first attack }\end{array}$ & $\begin{array}{l}\text { Streptomycin, INH, PAS, } \\
\text { prednisone, heparin, cytosine } \\
\text { arabinoside }\end{array}$ \\
\hline 7 & $\mathbf{M}$ & 26 & $\mathbf{R}$ & $0 \cdot 2$ & $\begin{array}{l}1 \cdot 0 \\
1 \cdot 3\end{array}$ & $\stackrel{*}{5}$ & $*$ & $\begin{array}{l}\text { Pulmonary tuberculosis } \\
22 \text { yrs earlier }\end{array}$ & $\begin{array}{l}\text { Streptomycin, INH, PAS, } \\
\text { prednisone }\end{array}$ \\
\hline 8 & $\mathbf{M}$ & 42 & $\stackrel{\mathbf{R}}{\mathbf{L}}$ & $0 \cdot 15$ & $\begin{array}{l}1 \cdot 3 \\
1 \cdot 3\end{array}$ & * & $*$ & $\begin{array}{l}\text { Pulmonary tuberculosis } \\
19 \text { yrs earlier }\end{array}$ & Vasodilators \\
\hline 9 & $\mathbf{F}$ & 50 & $\mathbf{R}$ & $1 \cdot 0$ & $1 \cdot 0$ & 5 & 5 & $\begin{array}{l}\text { Two brothers died from } \\
\text { pulmonary tuberculosis } \\
\text { Oestrogen therapy before } \\
\text { ocular symptoms }\end{array}$ & $\begin{array}{l}\text { Streptomycin, INH, PAS, } \\
\text { prednisone, azathioprine }\end{array}$ \\
\hline
\end{tabular}

* Not known

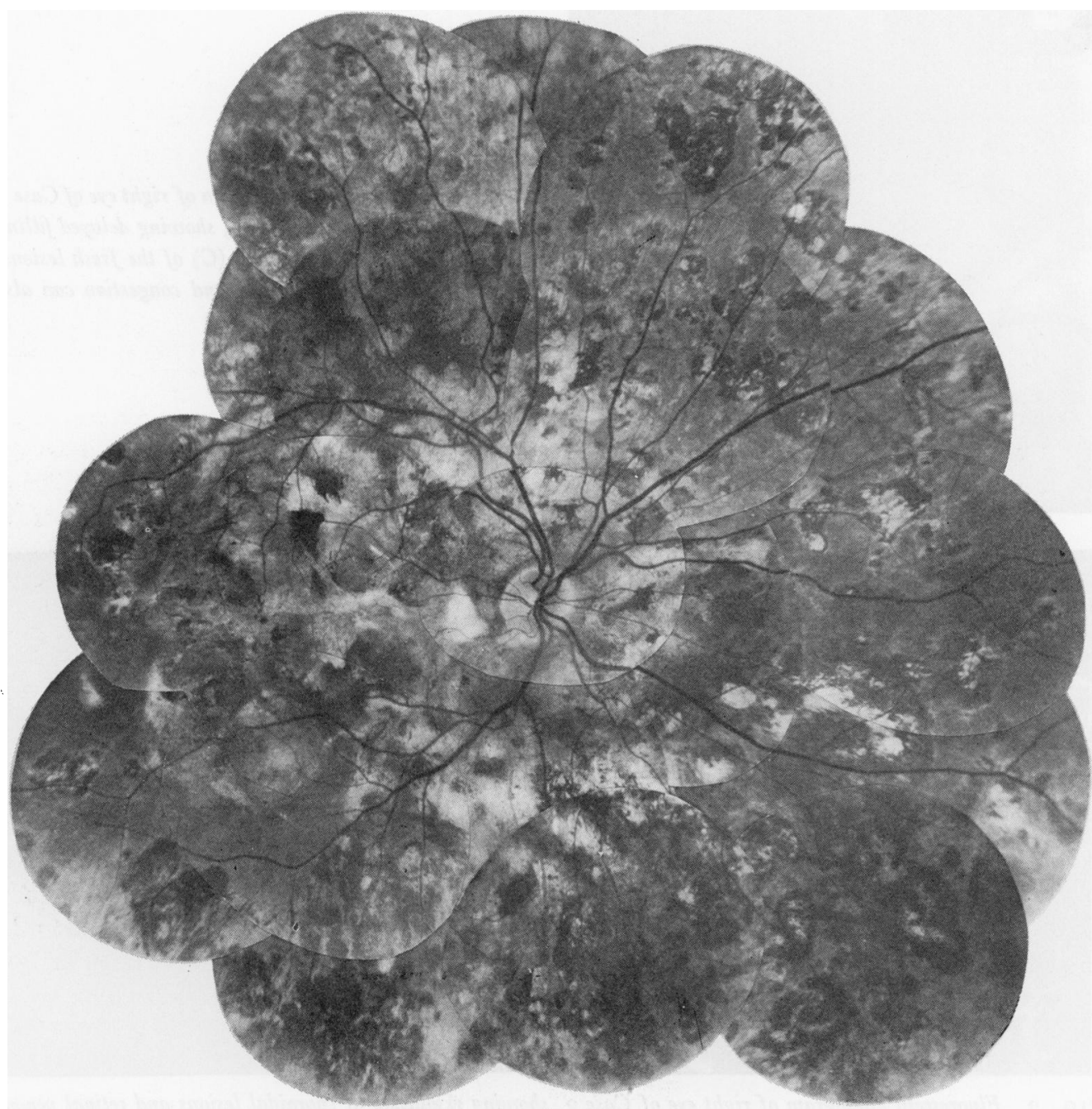

FIG. 4 Disseminated choroidal scars in initially affected right eye of Case 6 
In one patient (Case 6), the initial diagnosis had been chorioretinitis with oedema of the optic disc corresponding to findings in the uniocular cases of Group A presented above; the other patients were not seen at our hospital during the first attack. The visual acuity after recovery varied from $0 \cdot 15$ to $\mathrm{I} \cdot 3$.

Inflammation of the fellow eye reached the macula in all cases. The worst visual acuity varied from $0 \cdot 1$ to $I \cdot 0$, and the recovered vision from 0.8 to $\mathrm{I} \cdot 3$. A few cells could be seen in the vitreous, but no signs of anterior uveitis were observed. Ophthalmoscopic and fluorescein angiographic findings were very similar to those in Group A (Fig. 5 A-D). No changes were seen in the retinal vessels or in the optic disc. Healing of the individual lesions took 2 to 7 weeks and advanced centrifugally, but healing was not complete until 2 to 8 months from the commencement of the symptoms.

$(A)$
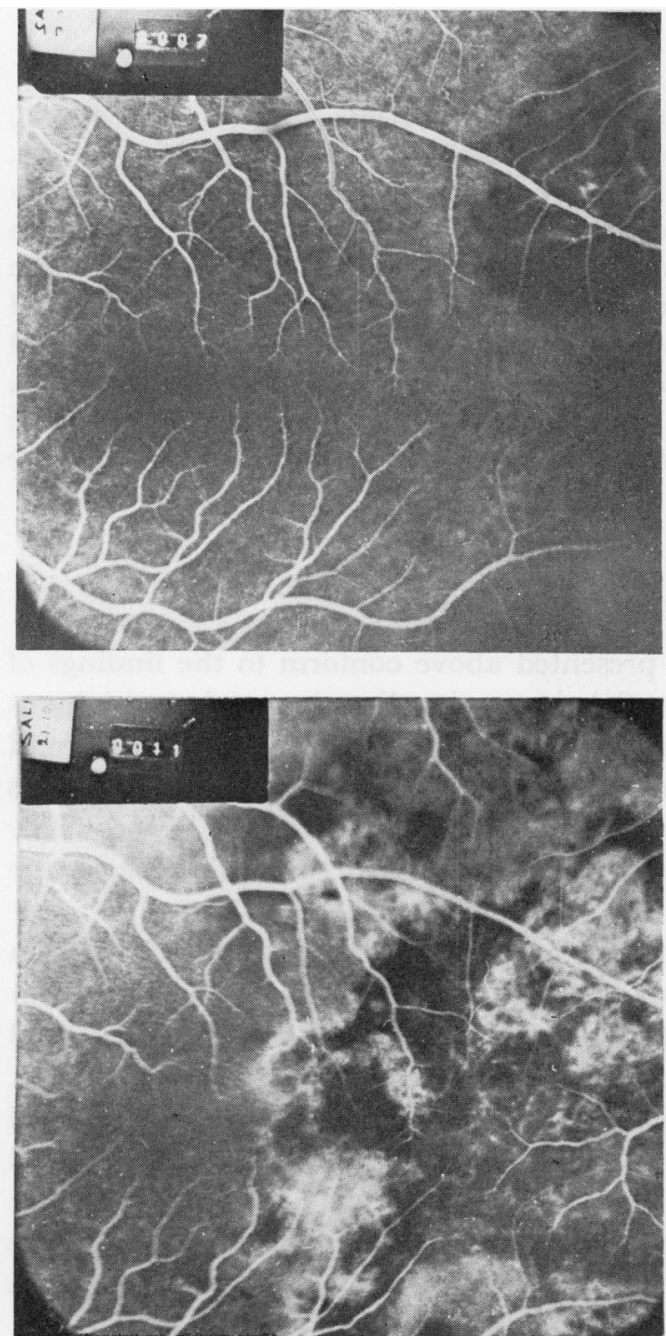

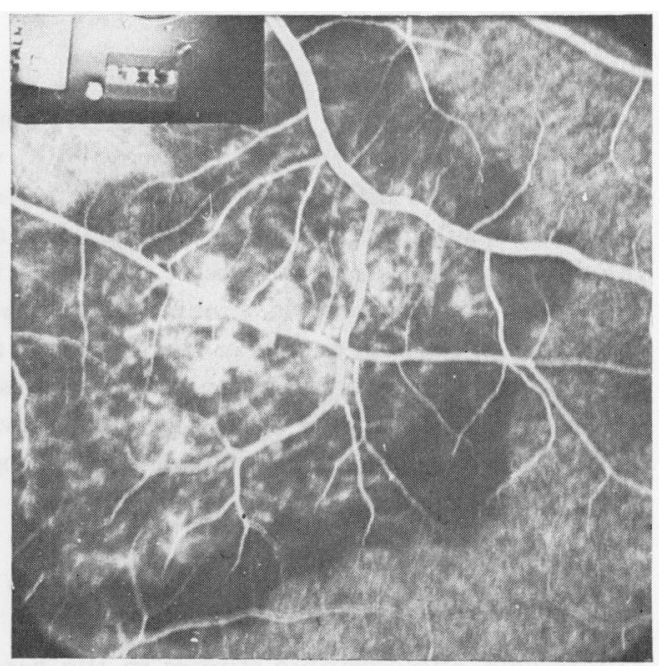

(B)

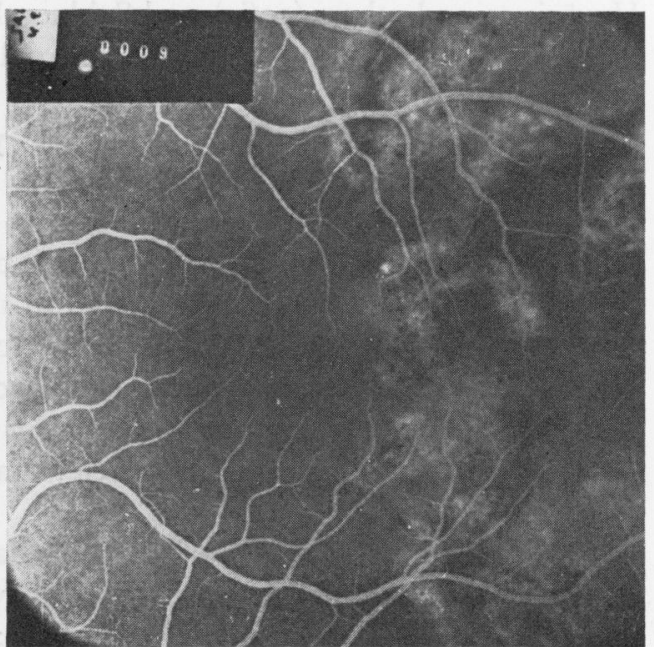

$(D)$

FIG. 5 Fluorescein angiogram of paramacular region of the left eye of Case 6 at onset of symptoms $(A)$, and I $m$ th later $(B)$, 3 mths later $(C)$, and 7 mths later $(D)$. An acute lesion shows delayed filling of the choriocapillaris $(A)$. After resolution, the choriocapillaris has disappeared in the middle of the lesion $(B)$. Hyperfluorescent margins of the scar areas $(C-D)$ are due to defects of the pigment epithelium

\section{Previous history}

As seen in Tables I and II, two patients in Group B had suffered from pulmonary tuberculosis 
about 20 years earlier, and two had a history of tuberculosis in the family. The Mantoux skin test was positive in all cases. One patient had had a virus meningitis 7 months before the first attack, and three had had an acute respiratory infection from I week to 2 months before the visual symptoms were noticed. No diagnostic changes in the virus antibody titres examined (vaccinia, herpes simplex, herpes zoster, cytomegalo, adeno, influenza $A$ and $B$, parainfluenza I, 2, and 3, parotitis, RS, rubella, rubeola, reo, polio $\mathrm{I}_{2} 2$ and 3 , coxsackie $\mathrm{A}_{7}, \mathrm{~A}_{9}$, and $\mathrm{B}_{5}$ ) could be found in any of the patients at the time of the ocular disease. Toxoplasma CF, ornithosis, and Mycoplasma pneumoniae titres showed no rise. Three patients had increased antistreptolysin titres (from 320 to 500), but no focal infection could be found. One female patient had been receiving treatment for menopausal symptoms with oestrogen-type hormonal therapy periodically during the last 2 years before the onset of symptoms in the previously sound eye.

\section{Treatment}

Tuberculostatic therapy with streptomycin, isoniazid (INH), or a combination of streptomycin, isoniazid, and para-amino salicylic acid (PAS) was given initially to seven patients. In four cases, this was combined with systemic prednisone beginning with 60 to $80 \mathrm{mg}$./day. One patient was given penicillin, a sulphatrimethoprim combination, and prednisone, and one patient was treated with vasodilators. In all cases the disease progressed for several months after the commencement of the medication. Two patients in Group B were treated with antimetabolites (cytosine arabinoside and azathioprine) because, in spite of tuberculostatic and cortisone therapy, the macular area and central vision of both eyes were threatened, and both showed some improvement after about one month. The oestrogen therapy in the female patient was stopped when the cortisone and antimetabolite medication was started. No signs of active tuberculosis or any other systemic infection could be observed during treatment.

\section{Discussion}

Fluorescein angiographic studies in the cases presented above conform to the findings of Hyvärinen and others (1969) and Schlaegel (1969) that major disturbances in serpiginous choroiditis were found in the choriocapillaris. Retinal vascular changes and the mild swelling of the optic disc observed in two of the uniocular cases may represent simultaneous retinal vasculitis. Slight venous and capillary congestion in the retina may also be secondary to papillitis caused by involvement of the ciliary blood supply to the optic disc by the disease process.

The slow progression and long duration of the disease can be referred to some long-term but relatively mild aetiological factor. In this respect, this disease differs from the multifocal placoid pigment epitheliopathy described by Gass (1968), although clinical and fluorescein angiographic findings in the acute stage of both conditions are very similar. Multifocal placoid pigment epitheliopathy does not seem, however, to be progressive and the ultimate scars are more superficial than in serpiginous choroiditis (Laatikainen and Erkkilä, 1973)

Tuberculosis or other foci of infection have been assumed to be the cause of serpiginous choroiditis by Witmer (1952) and Schlaegel (1969, 1972), but a degenerative origin has also been suggested (Schlaegel, I969, I972; Maumenee, I970).

The findings and the course of the disease in the patients presented above give some evidence for an immunological aetiology. No systemic disease was discovered in any of these patients at the time of the ocular disease, but two patients had suffered from pulmonary tuberculosis earlier in life, and the other patients all had a positive tuberculin skin test. Four patients had had some acute infection shortly before the eye disease, and one had an increased antistreptolysin titre without any signs of infection. Ingress into the blood 
of an infectious organism or some exotoxin may cause a clinical immunological manifestation in an allergically sensitized person. In the case of one patient, suspicion arises concerning the possibly deleterious effect of oestrogen therapy on the immunological system. A tubercular allergic aetiology may be assumed, at least in patients who had previously suffered from other kinds of tuberculosis.

Therapy consisted mainly of tuberculostatic medicines alone or in combination with prednisone. The effectiveness of the tuberculostatic medication is, however, questionable, since new lesions were observed several months after starting treatment. Tuberculostatic medication may, however, be indicated in patients with an earlier history of tuberculosis, in order to avoid activation of any other tuberculous process. Systemic prednisone in the doses used could not prevent progression of the disease. On the basis of our results, the use of antimetabolites seems to be indicated in cases with lesions close to the macula, especially if both eyes are involved.

\section{Summary}

The clinical and fluorescein angiographic findings in nine patients with serpiginous choroiditis are described. The history and clinical features and the course of the disease support the concept of an immunologically-induced choroiditis. In two patients, good therapeutic results were achieved with antimetabolites, which are recommended particularly in cases in which both maculae are threatened.

\section{References}

GASS, J. D. M. (1968) Arch. Ophthal. (Chicago), 80, I 77

hYVÄrinen, L., MAUMENEe, A. E., GeORge, T., and weinstein, G. w. (1969) Amer. F. Ophthal., 67, 653

LAATIKAINEN, L., and ERKKILÄ, H. (1973) Acta ophthal. (Kbh.), 51, 645

MAUMENEe, A. E. (1970) Amer. F. Ophthal., 69, I

SCHLAEGEL, T. F. (1969) 'Essentials of Uveitis', pp. 103-104. Churchill, London

- (1972) Ann. Ophthal., 4, 525

WITMER, R. (1952) Ophthalmologica (Basel), 123, 353 